\title{
A Study on Shortage of Nursing Staffs and Employment Security-An Empirical Study of Hangzhou City
}

\author{
Che Kai-li \\ School of Politics and Public Administration Zhejiang \\ University of Technology, \\ Hangzhou, China \\ 624336039@qq.com
}

\author{
Yang Yan-dong \\ School of Politics and Public Administration Zhejiang \\ University of Technology, \\ Hangzhou, China \\ yyd2002mail@163.com
}

\begin{abstract}
The construction of hardware facilities for pension institutions in China has developed rapidly in recent years. However, the number and quality of personnel engaged in nursing care work failed to keep up with the actual demand, and the stability of employees was low. Through the empirical study of 30 pension institutions in Hangzhou, we found that factors such as age, salary, leave, working conditions and labor intensity, labor contract, relationship with employer, occupational prestige and promotion opportunities have a significant impact on the work stability of nursing staff. Based on this, in order to solve the problem of unstable pension care worker teams, relevant intervention measures should be taken from the aspects of institution management, assessment system, salary guarantee and occupational status and so on.
\end{abstract}

Keywords-Pension institutions; Nursing staff; Employment stability; Influencing factors

\section{INTRODUCTION}

Into an aging society, the characteristics of aging, emptiness and incapacitation have become increasingly prominent, and the demand for socialized aged care services has been rapidly released. The institution of endowment insurance has been increasingly raised as an important support for the social pension service system. In recent years, the pace of construction of the social pension service system has accelerated rapidly throughout the country. The number of retirement beds and facilities has been growing steadily. Every 1,000 elderly people will have 40 or more old-age beds at the end of the 13th Five-Year Plan. However, from a practical point of view, the professionalization and professionalization of nursing staff are still very weak. The problems such as the shortage of manpower resources and the irrational structure are very prominent and can not meet the needs of the future. Take Hangzhou as an example. At present, the ratio of the number of beds in the pension institutions in the whole city to the number of pensioners is about 27: 1 [1]. According to the actual occupancy rate, each care worker needs to take care of about 11 old people. The low stability of employment and the high turnover rate of employees have become a serious obstacle to the development of the aged and service quality of the institutions. Which factors affect the stability of nursing staffs employment in pension institutions to a great extent, this paper intends to discuss this issue through empirical research on 30 pension institutions in Hangzhou.

Foreign researchers analyzed the influencing factors of the working stability of nursing care workers from multiple perspectives and conducted exploratory research on the corresponding intervention measures [2-3]. Due to the late development of pension services in socialized institutions in our country, the research on pension institutions in China only gradually increased in recent years. In a large number of studies focusing on the operation and operation of institutions, only a few studies have focused on the analysis of the working conditions of nursing staff in pension institutions and the research perspective mainly focuses on problem identification and countermeasure analysis [4-5]. Researchers have a certain consensus on the importance of stabilizing caregivers, but more profound exploratory research and causal research are still underway. The factors that affect the stability of nursing care workers are not only complex and diverse, but also change with different objective conditions. Based on the existing research results and combining with the field survey of pension institutions in Hangzhou, we set various relevant indicators, and then through the quantitative test and qualitative research, the influencing factors of different dimensions are classified and analyzed.

\section{THE DEFINITION OF Job StABILITY}

\section{A. Definition of working stability}

Taking the duration of an employee in the same unit as the standard, it is generally recognized that the work is more stable for more than five years in the international community. There is also the view that a flexible employment person who has been working for the same employer for more than three years can be regarded as basically stable. In addition, given the relatively late rise of socialized aged care services in China, the entry time of practitioners in this industry is generally short. In particular, many private pension institutions have only developed in recent years and their operation time is not long. Therefore, this article sets the working stability of the research object as follows: working in the same pension institution for 
more than three years (including three years) is considered to be basically stable, and when it reaches more than five years, the work can be regarded as relatively stable.

\section{B. Indicators set}

In this paper, the factors that affect the stability of care workers in nursing homes are divided into five dimensions, each of which contains 3-4 specific elements. Five dimensions are "personal characteristics", "salary and welfare", "working conditions and labor intensity", "labor relations" and "professional reputation and development".

"Personal characteristics" contains age, gender, professional skill level and education level. "Salary and welfare" contains salary income, social insurance, welfare subsidies and paid leave. "Working conditions and labor intensity" contains operating hours, labor intensity, working environment. "Labor relations" contains labor contract, employers and colleagues, relationship with the service object and trade union situation. "Professional reputation and development" contains on-the-job training, promotion opportunities and professional reputation. Whether the five elements of the five dimensions have a practical impact on the work stability of pensioners, this paper is to test the data analysis of the questionnaire.

\section{Research methods}

This paper mainly uses the methods of questionnaire survey and interview to collect data, the surveyed areas are Hangzhou where the level of aging is among the highest in the country, and the development of pension service institutions is developing rapidly. The survey respondents were first-line nursing staff in pension institutions, and the interviewees included care workers and administrative staff. Questionnaire is designed for personal characteristics, pay and benefits, working conditions and labor intensity, labor relations, job reputation and development of five major items. The 18 elements in Table 1 were defined operationally. The social insurance and welfare subsidy were decomposed according to the specific types of insurance and subsidy items. The labor intensity was defined as the number of caregivers for each care worker. A total of 25 operational indicators .Firstly, $\mathrm{T}$ test and analysis of variance (ANOVA) were used to test the correlation of each factor, and then to further discuss the subjective factors that the test results failed to reflect in combination with qualitative research.

\section{DATA COLLECTION AND SAMPLE CHARACTERISTICS}

In recent years, Hangzhou's pension service institutions have developed rapidly, but the nursing staffs continue to suffer a shortage. The sample of this survey is selected within the scope of the main urban areas with higher social level and relatively better construction conditions. Using stratified sampling method, six pension institutions were randomly selected from each of the five districts in Hangzhou. The nature of operation included three different types: public-run, non-profit-oriented and public-private. 490 questionnaires were issued, of which 465 were effectively recovered. The coverage rate of care workers in these 30 pension institutions was over $95 \%$.

\section{A. The demographic characteristics of the survey sample}

In the survey sample, the majority of female pensioners occupy the vast majority of employees, the relatively low level of education and the low level of professional skills, and more than half of them have obtained certificates of primary nursing care.

TABLE I. DISTRIBUTION OF PERSONAL CHARACTERISTICS OF RESPONDENTS

\begin{tabular}{c|c|c}
\hline \multicolumn{2}{c|}{ Classification index } & $\begin{array}{c}\text { Ratio } \\
(\mathbf{1 0 0 \%})\end{array}$ \\
\hline \multirow{2}{*}{ gender } & male & $13.60 \%$ \\
& female & $86.40 \%$ \\
\hline \multirow{2}{*}{ age } & 30 years old and below & $5.90 \%$ \\
& $31-40$ years old & $7.70 \%$ \\
& $41-50$ years old & $37.80 \%$ \\
education level & $51-60$ years old & $46.50 \%$ \\
& H1 years old and above & $2.10 \%$ \\
\hline \multirow{2}{*}{ Technical titles } & Unigh school and specialist & $17.80 \%$ \\
(Nursing care & Undergraduate and above & $2.10 \%$ \\
professional) & no no & $15.7 \%$ \\
& intermediate & $65.0 \%$ \\
& advanced & $16.4 \%$ \\
\hline
\end{tabular}

\section{B. Investigate the economic and working conditions of the sample}

1) Economic status

Respondents' salaries include basic salary and performance bonus. Monthly income in 2001-3000 accounted for 58.7\% of the total,20.6\% in 3001-4000 yuan, $18.9 \%$ of personnel monthly income level is less than 2000 yuan. $43.0 \%$ of the respondents said that pension institutions did not pay social insurance for them. In terms of housing benefits, most pension agencies provide free staff quarters, while a few agencies give their employees proper rental subsidies. $95.1 \%$ of the respondents said that the agency can grant a small amount of welfare subsidies except for paid vacation can not be guaranteed.

\section{2) Working condition}

$98.6 \%$ of the respondents worked more than 8 hours a day, $57.3 \%$ of them worked more than 12 hours, and even a few caregivers of the elderly who were disabled showed that they needed 24-hour escort due to manpower shortage. In terms of labor intensity, $54.9 \%$ of care workers care for more than seven elderly people, and fewer than four elderly people take care of nursing care in pension institutions with low occupancy rates. $78.7 \%$ feel more satisfied with the working environment of pension institutions. 


\section{3) Labor relations}

Of the 30 pension institutions surveyed, the majority of them signed labor contracts with employees, and only $14.1 \%$ of the respondents did not sign labor contracts with employers. In joining the labor union, $43.7 \%$ said they were not sure whether the pension institutions they worked for were unionized and only 14\% knew and participated in the union organizations of the service agencies. In terms of interpersonal relations, $90.5 \%$ said they were better off with colleagues within the organization or only $9.4 \%$ of pensioners thought there was a problem with their employer or colleagues. Sixtyfour percent of nursing home care workers think they are happy with the elderly they care for, and only $1.4 \%$ are in difficulty with their care recipient.

\section{4) Occupational prestige and development}

$36.3 \%$ of the respondents did not approve of the occupational nursing care profession they engaged in, and considered that the social status of nursing care work was relatively low or very low. Only $19.9 \%$ of the respondents recognized the nursing care profession. On the job training side, most respondents indicated that they had attended at least one training session and $33.2 \%$ attended more than three job training sessions in the past year. $75.9 \%$ of pensioners think they have little or no room for career advancement, and only $4.1 \%$ think they have greater career advancement space or opportunity.

\section{5) Time engaged in nursing work}

Nearly half $(49.3 \%)$ of the employees in the survey sample did not work more than three years in stability, and $33.6 \%$ were nursing care workers who worked relatively well (more than five years).

\section{THE CORRELATION ANALYSIS OF INFLUENCING FACTORS ON THE STABILITY OF NURSING CARE WORKERS}

\section{A. Variable assignment}

The explanatory variables are the working stability of nursing staff. The measurement standard is divided into "0-3 years" (unstable), "3-5 years" (basically stable), "5 years or more" (more stable), and deal with them In accordance with the "order variables" assignment. The explanatory variable is 25 indicator elements in five dimensions. On the valuation method, gender, social security, welfare and other dichotomous variables are treated as virtual or categorical variables with the values 0 and 1 ; other explanatory variables of more than two factor levels are assigned according to the processing of the distance or ordinal variables.

\section{B. Test analysis}

According to the assignment of explanatory variables, the independent sample T-test was used to analyze the dichotomous variables, such as gender, working environment and service objects, and their correlation with job stability. For other explanatory variables, the one-way ANOVA method was used to test the impact of each factor on the working stability of nursing staff.
TABLE II.

THE RESULTS OF INDEPENDENT SAMPLE T TEST

\begin{tabular}{|c|c|c|c|c|c|c|}
\hline $\begin{array}{l}\text { Variable } \\
\text { name }\end{array}$ & & $\begin{array}{l}\text { sum of } \\
\text { square }\end{array}$ & df & $\begin{array}{l}\text { Mean } \\
\text { square }\end{array}$ & $\mathbf{F}$ & $\begin{array}{l}\text { Signifi } \\
\text { cance }\end{array}$ \\
\hline age & $\begin{array}{l}\text { Between groups } \\
\text { Within the group } \\
\text { total }\end{array}$ & $\begin{array}{l}15.997 \\
215.234 \\
231.231\end{array}$ & $\begin{array}{l}4 \\
281 \\
285\end{array}$ & $\begin{array}{l}3.999 \\
.766\end{array}$ & 5.221 & .000 \\
\hline $\begin{array}{l}\text { education } \\
\text { level }\end{array}$ & $\begin{array}{l}\text { Between groups } \\
\text { Within the group } \\
\text { total }\end{array}$ & $\begin{array}{l}4.048 \\
227.182 \\
231.231\end{array}$ & $\begin{array}{l}4 \\
281 \\
285\end{array}$ & $\begin{array}{l}1.102 \\
.808\end{array}$ & 1.252 & .289 \\
\hline Basic wage & $\begin{array}{l}\text { Between groups } \\
\text { Within the group } \\
\text { total }\end{array}$ & $\begin{array}{l}6.452 \\
224.779 \\
231.231\end{array}$ & $\begin{array}{l}4 \\
281 \\
285\end{array}$ & $\begin{array}{l}1.613 \\
.800\end{array}$ & 2.016 & .902 \\
\hline $\begin{array}{l}\text { Daily } \\
\text { working } \\
\text { hours }\end{array}$ & $\begin{array}{l}\text { Between groups } \\
\text { Within the group } \\
\text { total }\end{array}$ & $\begin{array}{l}7.982 \\
223.248 \\
231.231\end{array}$ & $\begin{array}{l}3 \\
282 \\
285\end{array}$ & $\begin{array}{l}2.661 \\
.792\end{array}$ & 3.361 & .019 \\
\hline $\begin{array}{l}\text { Labor } \\
\text { intensity }\end{array}$ & $\begin{array}{l}\text { Between groups } \\
\text { Within the group } \\
\text { total }\end{array}$ & $\begin{array}{l}6.101 \\
225.130 \\
231.231\end{array}$ & $\begin{array}{l}3 \\
282 \\
285\end{array}$ & $\begin{array}{l}2.034 \\
.798\end{array}$ & 2.547 & .056 \\
\hline $\begin{array}{l}\text { The signing } \\
\text { of the } \\
\text { contract }\end{array}$ & $\begin{array}{l}\text { Between groups } \\
\text { Within the group } \\
\text { total }\end{array}$ & $\begin{array}{l}6.984 \\
224.246 \\
231.231\end{array}$ & $\begin{array}{l}3 \\
282 \\
285\end{array}$ & $\begin{array}{l}2.328 \\
.795\end{array}$ & 2.928 & .034 \\
\hline $\begin{array}{l}\text { Relationship } \\
\text { with } \\
\text { employer }\end{array}$ & $\begin{array}{l}\text { Between groups } \\
\text { Within the group } \\
\text { total }\end{array}$ & $\begin{array}{l}14.764 \\
216.467 \\
231.231\end{array}$ & $\begin{array}{l}3 \\
282 \\
285\end{array}$ & $\begin{array}{l}4.921 \\
.768\end{array}$ & 6.411 & .000 \\
\hline $\begin{array}{l}\text { On-the-job } \\
\text { training }\end{array}$ & $\begin{array}{l}\text { Between groups } \\
\text { Within the group } \\
\text { total }\end{array}$ & $\begin{array}{l}4.669 \\
226.562 \\
231.231\end{array}$ & $\begin{array}{l}3 \\
282 \\
285\end{array}$ & $\begin{array}{l}1.556 \\
.803\end{array}$ & 1.937 & .124 \\
\hline $\begin{array}{l}\text { Career } \\
\text { promotion } \\
\text { opportunitie } \\
\mathrm{s}\end{array}$ & $\begin{array}{l}\text { Between groups } \\
\text { Within the group } \\
\text { total }\end{array}$ & $\begin{array}{l}7.675 \\
223.556 \\
231.231\end{array}$ & $\begin{array}{l}4 \\
281 \\
285\end{array}$ & $\begin{array}{l}1.919 \\
.796\end{array}$ & 2.412 & .049 \\
\hline $\begin{array}{l}\text { Professional } \\
\text { reputation }\end{array}$ & $\begin{array}{l}\text { Between groups } \\
\text { Within the group } \\
\text { total }\end{array}$ & $\begin{array}{l}60.029 \\
528.111 \\
588.140\end{array}$ & $\begin{array}{l}4 \\
281 \\
285\end{array}$ & $\begin{array}{l}15.007 \\
1.879\end{array}$ & 7.985 & .000 \\
\hline $\begin{array}{l}\text { trade union } \\
\text { organization }\end{array}$ & $\begin{array}{l}\text { Between groups } \\
\text { Within the group } \\
\text { total }\end{array}$ & $\begin{array}{l}11.937 \\
219.294 \\
231.231\end{array}$ & $\begin{array}{l}2 \\
283 \\
285\end{array}$ & $\begin{array}{l}5.969 \\
.775\end{array}$ & 7.702 & .001 \\
\hline $\begin{array}{l}\text { technical } \\
\text { title }\end{array}$ & $\begin{array}{l}\text { Between groups } \\
\text { Within the group } \\
\text { total }\end{array}$ & $\begin{array}{l}5.522 \\
225.709 \\
231.231\end{array}$ & $\begin{array}{l}3 \\
282 \\
285\end{array}$ & $\begin{array}{l}1.841 \\
.880\end{array}$ & 2.300 & .078 \\
\hline
\end{tabular}

From the $\mathrm{T}$ test results of 13 indicators in Table 2 , the factors such as "Performance Bonus, Paid Leave, Housing Welfare, and Working Environment" reached a significant level, that is, there is a correlation between the length of the current working hours for nursing care workers and the changes in these factors. While the "gender, five social insurance, transportation, restaurant subsidies, and service objects" and other factors did not pass the test of significance.

After single-factor test ANOVN, the results of variance test of the 12 indicators show that the factors such as age, working hours, contract signing, employer and colleague relationship, trade union, career promotion and occupational prestige reach the significant level, but education level, technical title, basic salary, Labor intensity, on-the-job training and other factors did not pass the test of significance.

\section{Test results and discussion}

$\mathrm{T}$ test and analysis of variance were used to test the relationship between each factor and the working stability of nursing staff. There were 11 elements that passed the test of significance and the other factors did not reach the significant level. The test results are shown in Table 3: 
TABLE III. NURSING CARE WORKERS WORKING STABILITY OF THE QUANTITATIVE TEST RESULTS

\begin{tabular}{l|l|l}
\hline Dimension & Significant correlation & $\begin{array}{l}\text { Non-significant } \\
\text { correlation }\end{array}$ \\
\hline $\begin{array}{l}\text { Personal } \\
\text { characteristics }\end{array}$ & age & $\begin{array}{l}\text { Gender, education level, } \\
\text { technical title }\end{array}$ \\
$\begin{array}{l}\text { Salary and } \\
\text { welfare }\end{array}$ & $\begin{array}{l}\text { Performance bonuses, } \\
\text { housing benefits, paid leave }\end{array}$ & $\begin{array}{l}\text { Social Security, Basic } \\
\text { Wages, Transportation } \\
\text { and Catering Allowance }\end{array}$ \\
$\begin{array}{l}\text { Working } \\
\text { conditions and } \\
\text { labor intensity }\end{array}$ & $\begin{array}{l}\text { Daily working hours, } \\
\text { working environment }\end{array}$ & $\begin{array}{l}\text { Labor intensity } \\
\text { Labor relations }\end{array}$ \\
$\begin{array}{l}\text { The signing of the contract, } \\
\text { employer-employee } \\
\text { relationship, trade union } \\
\text { organization }\end{array}$ & $\begin{array}{l}\text { Relationship with the } \\
\text { service object }\end{array}$ \\
$\begin{array}{l}\text { Professional } \\
\text { reputation and } \\
\text { development }\end{array}$ & $\begin{array}{l}\text { Career promotion } \\
\text { opportunities, recognition of } \\
\text { career prestige }\end{array}$ & On-the-job training \\
\hline
\end{tabular}

For those elements that did not pass the correlation test, the investigators further analyzed the causes by using qualitative methods such as in-depth interviews and feature comparison. The interviewees were managers of nursing home institutions and some nursing staff. Combining the results of quantitative and qualitative analysis, the following conclusions are drawn:

First, older female nursing staffs with lower educational level have relatively higher job stability. In reality, the shortages of nursing care workers are not only the absolute deficiency in quantity, but also the relative structural deficiencies. The main problems are as follows: firstly, there is a serious imbalance between the male and female sex ratio of the nursing staff and few male nursing staff; Secondly, highly educated, highly skilled, young caregivers a serious lack of. From the perspective of pension institutions, it is even more important to have a stable workforce and to retain skilled employees who are comfortable with the job, so some agencies do not deliberately pursue the specialization and rejuvenation of nursing home nurses. But more realistic tendencies to hire four or five years old, able to work hard low educated working women. In fact, under the current remuneration packages and professional prestige of the nursing care profession, only such groups can hold their jobs relatively steadily.

Second, nurses are willing to accept high-intensity service on the condition that they can get the corresponding high pay for performance. The shortage of nursing staff in institutions and excessive labor intensity falls into a vicious cycle that is hard to digest. The multi-labors incentive utility is especially important. Nurses pay more attention to the bonus income rather than the lower basic salary. This has also led to this phenomenon among pension institutions with different occupancy rates: in terms of labor intensity, institutions with low occupancy rates and few care targets may be lower than those with high occupancy rates and high levels of care. However, in terms of employee turnover, institutions with high occupancy rates and more care may be lower than those with low occupancy rates and low attendance rates because of the need to do work and bonuses. This shows that it may not be realistic to infer that high labor intensity will inevitably lead to employee turnover only from the shallow cognition. In terms of labor intensity and salary income, low-paid laborers pay more attention to remuneration compensation due to high labor intensity.

Third, difficult to enjoy the normal paid leave is an important reason for the high turnover rate of care workers. Long working hours and less vacation are the prominent features of the nursing care profession and also the reasons why many high-quality and professional nursing staffs are not willing to enter the job. In many organizations, due to lack of manpower, fewer retirements allow pensioners not only to have normal weekend and holiday vacations but also to caregivers of the disabled elderly people even to stay for 24 hours. In many agencies, due to lack of manpower, there is little adjustment for retirement, and it is very hard for pensioners to have regular weekends, holidays and vacations, and the caretakers who care for disabled elderly people even have to stay for 24 hours. In the long run, many caregivers' families can not accept this. This working condition is the main crux of the pensions care industry that hires people and keeps people in difficulty.

Fourth, the benefits of food and clothing have a positive effect on attracting and retaining pensioners. The maintenance of food and clothing in the hospital is both a requirement of the nature of work and a common practice in nursing homes. Care workers in pension agencies are mostly migrant workers. In cities with high housing prices, accommodation costs are a large sum of money. For migrant workers who are difficult to settle, the provision of free accommodation and meals by pension institutions is their comparatively important occupational welfare, and also makes the pension service more attractive than other service industries.

Fifth, normative labor relations and a harmonious working atmosphere help to stabilize and retain aged care workers. With the improvement of workers' rights and interests, the signing of labor contracts and the protection of trade union organizations are also increasingly valued by pensioners. This also reflects the desire of many aged care workers to have long-term and formal employment. Nursing care is a professional and technical position which need for long-term clinical experience. The longer the length of service and the more experienced the workforce, the higher the income level of practitioners and the stronger their will to engage in this profession for a long time. If the hospital can provide as much respect and reward for conservation personnel as possible in these fields, it will be helpful to standardize and stabilize the employment of nursing care workers. In reality, the social recognition of nursing care work is not high enough, career opportunities are less, it is difficult to attract and retain highquality professional nurses [6].

Sixth, at present, although many nursing graduates trained by universities and colleges are gradually delivering to the society, there are still a few who are actually engaged in nursing work in pension institutions. Traditional attitudes still regard the professional services of elders as "wait-and-seers", which results in younger professionals preferring to go to 
hospitals rather than to nursing homes. Under the circumstance that the demand for medical staff in the hospital is still high, the nursing staff in pension institutions can not compare with the talent competitiveness of the hospital both in terms of professional reputation and salary. Therefore, the professionalization of pension care workers is still a long way to go.

\section{SUMMARY}

Based on the above conclusions, this paper argues that in order to speed up the development of the pension service industry and solve the problems of low stability, recruit people and difficulties in retaining the pension care workers, we can consider strengthening the corresponding measures from the following aspects:

First, we should standardize the management evaluation system for pension institutions, intensify the assessment of the ranks of institutional care workers, incorporate the labor protection and welfare benefits of pensioners into the institutional evaluation system as a rigid indicator, strengthen supervision and evaluation of the treatment of employees in private retirement institutions, scrutinize the signing of labor contracts, supervise pension institutions to establish normal functioning trade union organizations, and rectify and punish pension institutions with more labor disputes.

Second, strictly formulate and implement the "care-andover ratio" standard for pension institutions, the proportion of care and placement of caregivers should be clearly defined in the management system of local pension institutions, and subsidies should be given to those institutions that are equipped with pensioners according to the regulations.

Thirdly, we should establish a mechanism for the normal growth of pension care workers' wages, guide and supervise the retirement institutions to strictly control the labor intensity of nursing staff, and gradually eliminate the unreasonable incentive measures that increase the labor performance and increase the performance income of care workers. Encourage retirement institutions to purchase supplements such as commercial endowment insurance and health insurance for their employees so as to enhance employee welfare care.

Fourth, to encourage retirement institutions is to introduce paid leave for nurses, increase re-adjustment and enhance the flexibility of work arrangements. Explore various channels to replenish the human resources for aged care services, fully exploit and utilize potential aged care workers, advocate volunteer activities, encourage volunteers to participate in aged care services with public service credit points, and encourage family members to visit, pick up and care for the elderly on holidays [7].

Fifth, strengthen the public service of public service for pension services, change social awareness and improve the occupational reputation of pension services. At the same time, we should increase the attractiveness of pension service occupations by increasing incomes, improving treatment and upgrading the professional skills of pension care workers so as to enhance the professional identity of practitioners and stabilize the workforce.

\section{ACKNOWLEDGMENT}

Zhejiang Philosophy and Social Sciences Planning Project (15NDJC170YB); Scientific and technological innovation plan of college students in Zhejiang (Xinmiao Talents Project) (2016R403059).

\section{REFERENCES}

[1] Chen Xue-ping. Investigation and Countermeasure on the Status Quo of Pension Institutions Serving the Old in [J]. Journal of Nursing Science, 2008 (21):13-15

[2] Tilja I.J.vanden Berg, Jan A Landeweerd, Gladys E.R.Tummers, Godefridus G.van Merode.A comparative study of organisational characteristics,work characteristics and nurses'psychological work reactiona in a hospital and nursing home setting. International Journal of Nursing Studies.2005, 43,491-505.

[3] Susan Letvak, Christopher J. Ruhm. The Impact of Worker Health on Long Term Care: Implications for Nursing Managers. Geriatric Nursing, 2010, 31,165-169.

[4] Mu Guang-zong. The Plight and Countermeasure of the Development of China's Aged [J]. Journal of Huazhong Normal University (Humanities and Social Sciences), 2012, 02:31-38.

[5] HuangFei.The Current Situation and Demand of Nursing Staff Training in Pension Institutions in Liaoning Province[J].Chinese Journal of Gerontology,2012(2): 570-572.

[6] Shi Yan-Ting, Yu Chang-mei. Investigation on the Current Situation of Working, Training and Practicing of Nursing Nurses in Wenzhou City [J]. Nursing research, 2013 (30): 3340-3341.

[7] Fang Li-Ming. Study on the Forming Mechanism and Development Strategy of the Contradiction between Supply and Demand of Nursing Nurses [J]. Aging science research, 2013, 01:56-64. 